\title{
Supraglottic Cancer TNM Finding v7
}

National Cancer Institute

\section{Source}

National Cancer Institute. Supraglottic Cancer TNM Finding v7. NCI Thesaurus. Code C89049.

A finding about one or more characteristics of supraglottic cancer, following the rules of the TNM AJCC v7 classification system. 